\title{
In situ localization of heat-shock proteins and cell death labelling in the salivary gland of acaricide-treated honeybee larvae* $^{*}$
}

\author{
Elaine C.M. Silva-ZACARIN ${ }^{\mathrm{a}}$, Ales GREGORC ${ }^{\mathrm{b}}$, Regina L.M. SILVA DE MORAES ${ }^{\mathrm{c}}$ \\ ${ }^{a}$ Federal University of São Carlos, UFSCar, Sorocaba, SP, Brasil \\ ${ }^{\mathrm{b}}$ Agricultural Institute of Slovenia, Hacquetova 17, 1001 Ljubljana, Slovenia \\ ${ }^{\mathrm{c}}$ Departamento de Biologia, I.B., Universidade Estadual Paulista (UNESP), Av. 24 A, n. 960, CEP: 13506-700, \\ PO Box 199, Rio Claro/SP, Brazil
}

Received 18 August 2005 - revised 19 November 2005 - accepted 22 November 2005

\begin{abstract}
The effects of the acaricides, rotenone and oxalic acid (OA) on salivary glands of honeybee larvae were evaluated. Immunohistochemical methods were used to detect cell death and heat-shock protein (HSP70 and 90) localizations. Heat-shock proteins (HSP70 and 90) were localized in the cytoplasm and/or the nuclei of secretory gland cells, both under stress and in normal conditions. In rotenone-treated larvae, there were no changes in the normal level of cell death and also there were no morphological alterations in the secretory cells. In the larvae treated with oxalic acid, the salivary gland showed varying degrees of morphological cellular alteration and an increase in the cell death level. The present data suggest that stressinduced HSP70 might have an antiapoptotic effect while the stress-induced HSP90 might have a chaperone function in the larval salivary glands.
\end{abstract}

Apis mellifera / silk gland / cellular stress / immunohistochemistry / rotenone / oxalic acid

\section{INTRODUCTION}

In many parts of the world the threat of the damaging effects of the parasitic Varroa destructor mite (Acari: Varroidea) forces beekeepers to treat their colonies with acaricides. As a result, acaricides are the most common chemical stressor that honeybee larvae experience in the field. Immunocytochemical studies of cell death and the localization of heat-shock proteins in the larval tissues of honeybees after acaricide applications, have helped to better understand the possible adverse effects acaricides may have on beehives (Gregorc and Bowen, 1999, 2000).

A variety of stressful stimuli can induce a cellular accumulation of heat-shock proteins,

Corresponding author: E.C.M. Silva-Zacarin, elaine@power.ufscar.br

* Manuscript editor: Klaus Hartfelder known as HSP's (Lindquist and Craig, 1988), originally described in cells exposed to heat. HSP's, which mainly function as molecular chaperones, allow cells to adapt to gradual changes in their environment and to survive in otherwise lethal conditions. The events of cell stress and cell death are linked and HSP's, induced in response to stress, appear to function at key regulatory points in the control of programmed cell death or apoptosis (Garrido et al., 2001).

When heat-shock proteins function under normal cellular conditions, they are essential components in a number of diverse biological processes (Pelham, 1986; Chiang et al., 1989; Rassow et al., 1995). They are classified according to their molecular weight and the HSP70 family constitutes the most frequently observed and best-studied class of HSP's (Lindquist and Craig, 1988). 
Under various conditions of stress, the synthesis of stress-induced HSP70 can inhibit cell death and thereby increase the survival of cells exposed to a wide range of lethal stimuli (Mosser et al., 1997). Overexpression of HSP70 suppresses mitochondrial damage and nuclear fragmentation (Buzzard, 1998) and therefore functions as a potent antiapoptotic protein (Garrido et al., 2001). HSP90 is also induced under stress conditions, but its function is less clear than that of the HSP70 family. According to Garrido et al. (2001), the overexpression of the HSP90 seems to have different effects in stressed cells, depending on the type of stimulus. The sensitivity of the HSP system to induction by a wide variety of chemical or physical stressors makes it attractive as a biomarker to evaluate the biological effects of exposure to any given toxic agent (Pomerai, 1996).

Monoclonal antibodies have been used to determine the presence of HSP's in different tissues (Chiang et al., 1989). Anti-HSP antibodies were used as markers to identify the effects of toxic metals on terrestrial isopods and terrestrial and marine molluscs (Kohler et al., 1992). Gregorc and Bowen (1999) suggested that the use of techniques to detect HSP's, associated with cell death labelling, could help to diagnose bee infections and evaluate the effects of acaricide applications on bees. Immunocytochemical methods are useful in labelling cell death, which has been detected in the honeybee midgut after a P. larvae infection and after acaricide applications (Gregorc and Bowen, 1998, 2000; Gregorc et al., 2004), and also in the isolated heart of the honeybee after exposure to herbicides (Papaefthimiou et al., 2002).

The aim of this work was to determine whether treating honeybee larvae with an "alternative" Varroa control substance, such as oxalic acid, or with an acaricide, such as rotenone, could induce the overexpression of HSP's and/or cell death in the salivary glands of Apis mellifera. The salivary glands of larval insects are good models to study the mechanisms of cell death (Bowen and Lockshin, 1981) and the morphological changes during their normal degeneration process are well defined (Silva, 2002). Since these glands are capable of absorbing substances from haemolymph (Levy and Bautz, 1985; Armbruster et al., 1986; Meirelles et al., 2001), such compounds could accelerate the cell death process in this gland or change the expression of stress proteins. Therefore, larval salivary glands might become a key organ in toxicological studies of bees.

\section{MATERIALS AND METHODS}

\subsection{Treatment of bee larvae}

Apis mellifera L. larvae were treated on the comb with either an oxalic acid/sucrose solution or rotenone. The oxalic acid solution $(\mathrm{OA})$ was prepared from $6.5 \mathrm{~g}$ oxalic acid dihydrate (Kemika, Zagreb, Croatia) and $50 \mathrm{~g}$ sucrose in $100 \mathrm{~mL}$ deionized water. The concentration of OA/sucrose was $2.97 \% / 31.95 \%(\mathrm{w} / \mathrm{w})$. The substance was sprayed directly onto larvae in comb cells, so that the dose received by each larva corresponded to $0.121 \mathrm{mg}$ of the OA solution.

Rotenone was sieved over the combs in order to spread the substance uniformly across the brood cells. The larvae were treated with $0.5 \mathrm{~g}$ of $1 \%$ rotenone so that each larva was treated with $0.29 \mathrm{mg}$ of the product.

The combs containing either the oxalic acid or rotenone treated larvae were then returned to their original colonies. A transparent foil was used to make a tracing of the combs, marking the open comb cells that contained larvae that were at the 3rd and at the beginning of 5th instar. These larvae were treated during the feeding phase, but they were collected at the spinning phase. Two lots of samples were taken after the treatments - one after 6 hours and another one after 48 hours. Larvae at the beginning of 5th instar were collected $6 \mathrm{~h}$ after acaricide application (at the end of 5th instar) and larvae at the 3 rd instar were collected $48 \mathrm{~h}$ after acaricide application, when they also had reached the end of 5th instar. Samples of untreated "control" larvae were also at the end of the 5th instar, and they were collected at the same time as those experimental group. These larvae were identified as being at the end of 5th instar according their characteristic anatomy and position inside the closed cell combs. Larval age was confirmed during the dissection process when it was possible to observe the silk secretion in the lumen of the salivary glands, as described by Silva-Zacarin et al. (2003). 
Three larvae from each of the experimental groups, as well as from the control group were dissected. Their salivary glands were isolated after excision from the ventral integument, characteristic of larvae that had reached the end of the 5th instar. The glands were fixed for $24 \mathrm{~h}$ in a $10 \%$ formol saline and they were then dehydrated in an ascending series of alcohol and xylene. Finally, the glands were embedded in wax as described by Gregorc and Bowen (1999). A Bright 5030 microtome was then used to cut $5 \mu \mathrm{m}$ sections, which were placed on Decon-cleaned slides and then air-dried. For the immunohistochemical assays, the slides were dewaxed by immersion in xylene and alcohol.

\subsection{Immunohistochemical localization of heat-shock proteins}

Endogenous peroxidase activity was blocked by an immersion in a methanol/hydrogen peroxide mixture $(47.2 \mathrm{~mL}$ of methanol and $0.8 \mathrm{~mL}$ of $30 \%$ hydrogen peroxide) for $30 \mathrm{~min}$ at room temperature. The sections were then washed under running tap water for $5 \mathrm{~min}$ and placed in phosphate buffer saline (PBS) (0.01 M, pH 7.0). The slides were blotted dry with paper tissue before covering with a primary antibody solution. The monoclonal antibodies against heat-shock protein 70 and 90 (HSP70 and HSP90) were obtained from Sigma. Antibodies were diluted up to one hundred fold in Tris buffer (pH 8.2) supplemented with $1 \%$ bovine serum albumin.

After incubating the primary antibodies overnight at $4{ }^{\circ} \mathrm{C}$, the sections were washed three times in PBS and covered with a secondary antibody conjugated with peroxidase. They were incubated for $30 \mathrm{~min}$ in a humidified chamber at room temperature. Novostain Super ABC Kit from Novocastra Laboratories was employed in this procedure and used in accordance with the test kit instructions. The sections were then incubated with peroxidase substrate (DAB or AEC) and washed in tap water for $5 \mathrm{~min}$. Counterstaining was accomplished by directly transferring the sections into Mayer's haematoxylin, washing and dehydrating them in three changes of alcohol and three changes of xylene and then mounting in DPX.

In the control sections, the respective primary antibody was omitted and the endogenous peroxidase activity was quenched. The slides were examined with a Nikon light microscope.

\subsection{Immunohistochemical labelling of cell death}

Using the "In situ cell death detection kit, AP" (ISCDDK; Roche), the dewaxed and rehydrated tissue sections were incubated with proteinase $\mathrm{K}$ for $15 \mathrm{~min}$. Labelling was conducted by covering the tissue sections with $30-40 \mu \mathrm{L}$ of a "TUNEL" reaction mixture, for $60 \mathrm{~min}$ at $37{ }^{\circ} \mathrm{C}$ in a humidified chamber. TdT-enzyme-incorporated fluorescein was detected with a "converter-AP" consisting of an anti-fluorescein antibody conjugated with alkaline phosphatase. The EnVision System alkaline phosphatase kit (Dako) was used to obtain a redcoloured precipitate. The sections were counterstained with haematoxylin. TUNEL-positive cells appeared red, whereas TUNEL-negative nuclei appeared blue.

Negative-control labelling was achieved by substituting the deoxynucleotidyl transferase (TdT) enzyme with PBS. The slides were examined with a Nikon light microscope.

\section{RESULTS}

\subsection{Untreated control larvae}

In the salivary glands of untreated control larvae (Fig. 1), HSP70 immunoreactivity was detected in most of the nuclei of secretory cells, and spots of reaction product were also observed in the basal cytoplasm (Fig. 1A,B). The localization of HSP90 immunoreactivity was similar to that described for HSP70 (Fig. 1C). A red azo-dye reaction product was found in many nuclei of the secretory cells of the salivary glands of the untreated larvae by using the ISCDDK test kit (Fig. 1D).

\subsection{Rotenone-treated larvae}

Six hours after the honeybee larvae were exposed to rotenone (Fig. 2), the level of positive-reaction product indicating HSP70 localization increased in most of the nuclei and the basal cytoplasm of secretory cells (Fig. 2A), in comparison with the untreated control larvae (Fig. 1B). However, HSP90 localized in a different manner to that described for the untreated control larvae. The reaction 

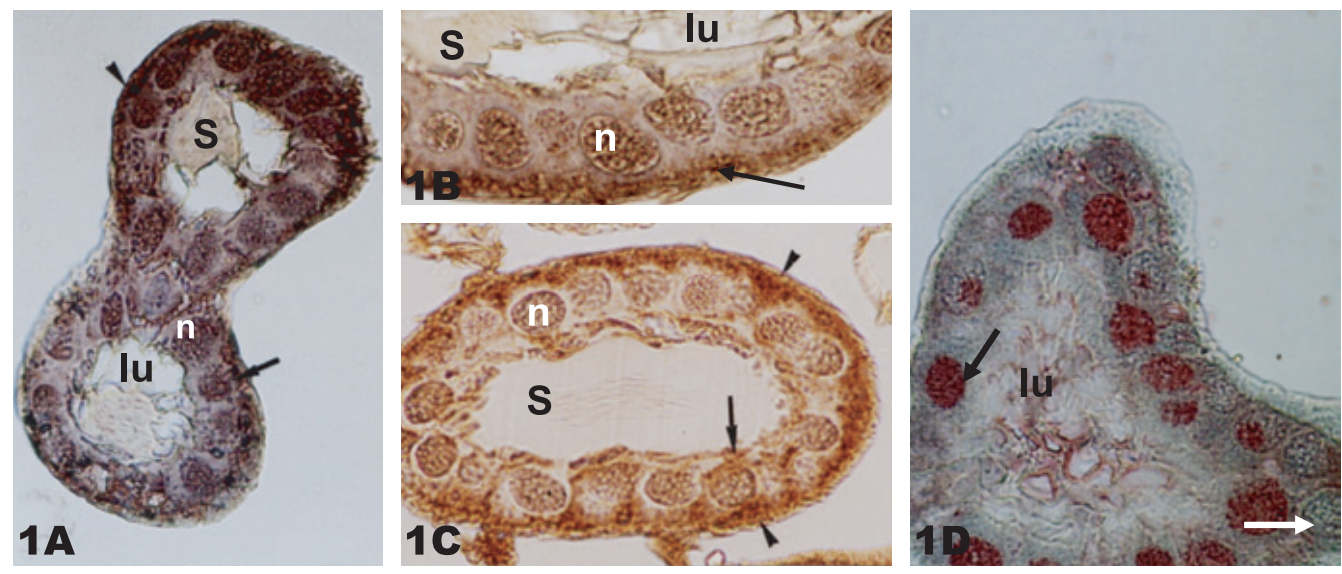

Figure 1. Secretory cells of formalin-fixed, paraffin-embedded salivary glands of untreated larvae at the end of the 5th instar. (A) and (B) Detection heat-shock protein 70 (HSP70) by a monoclonal antibody. (A) AECreaction product is localized in the nuclei (arrow) and in the basal cytoplasm (arrowhead). Magnification: 200×. (B) DAB-reaction product is localized in the nuclei (n) and the basal cytoplasm (arrowhead). Magnification: 400×. (C) Detection of heat-shock protein 90 (HSP90) by a monoclonal antibody. DAB-reaction product is localized in the nuclei (n) and in the basal cytoplasm (arrow). Some traces of DAB-reaction product can also be seen in the apical cytoplasm (arrow). Magnification: 300×. (D) Detection of programmed cell death by the ISCDDK system. Red azo-dye staining is localized in secretory cell nuclei (black arrow). White arrow indicate nucleus without red azo-dye staining. Magnification: $400 \times . S=$ secretion, lu = lumen.
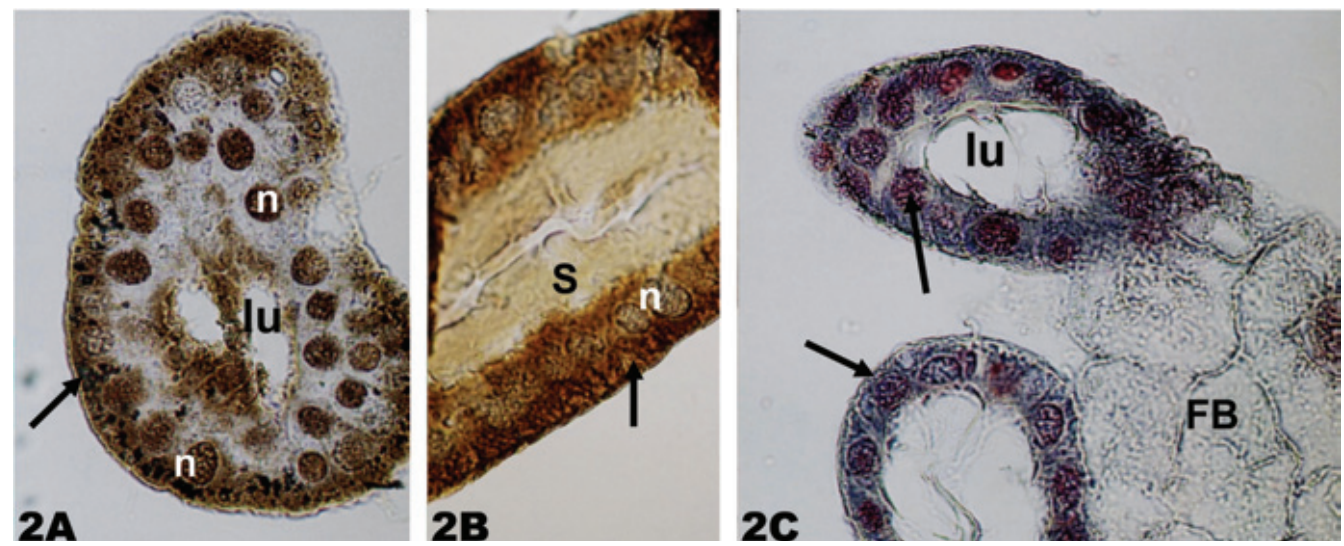

Figure 2. Secretory cells of formalin-fixed, paraffin-embedded salivary glands of larvae at the end of their 5th instar, collected 6 hours after the rotenone treatment. (A) Detection of HSP70 by a monoclonal antibody. DAB-reaction product is localized in the nuclei (n) as well as the basal cytoplasm (arrow). Magnification: $300 \times$. (B) Detection of HSP90 by a monoclonal antibody. Intensive DAB-reaction product (arrow) is localized throughout the cytoplasm, yet absent from the cell nuclei (n). Magnification: 300×. (C) Detection of programmed cell death by the ISCDDK system. Slight red azo-dye staining is localized within the secretory cell nuclei (arrow). Magnification: 200×. FB = fat body, $\mathrm{S}=$ secretion, lu = lumen. 

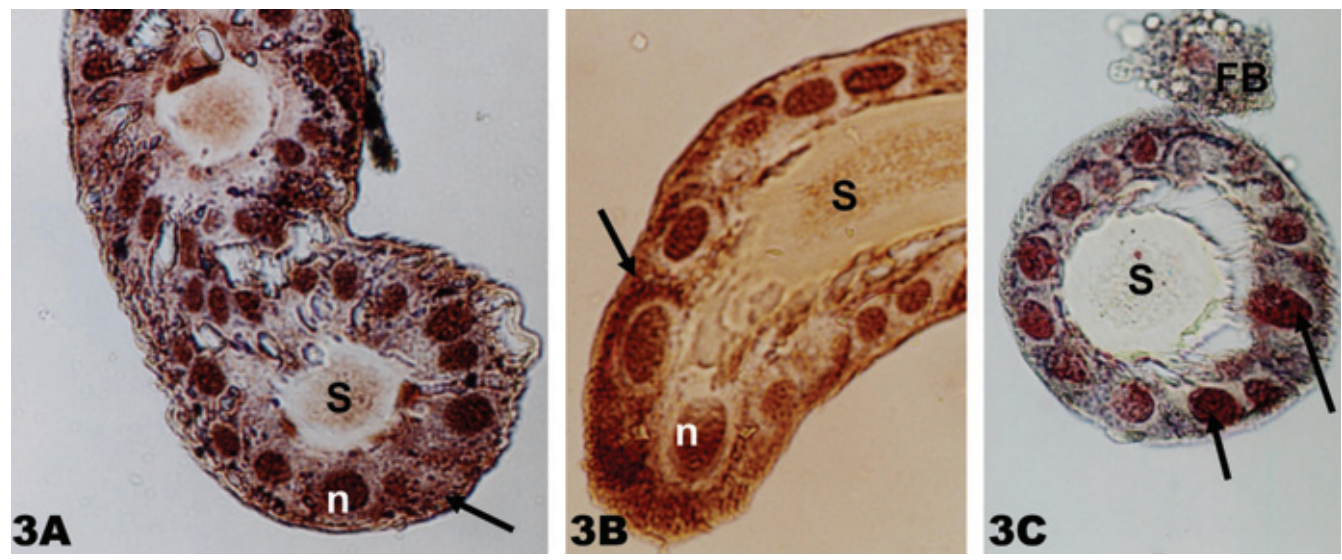

Figure 3. Secretory cells of formalin-fixed, paraffin-embedded salivary glands of larvae at the end of their 5th instar, collected 48 hours after the rotenone treatment. (A) Detection of HSP70 by a monoclonal antibody. AEC-reaction product (arrow) is clearly localized in the nuclei (n) and traces of this reaction product are dispersed throughout the cytoplasm (arrow). Magnification: 300×. (B) Detection of HSP90 by a monoclonal antibody. Intensive DAB-staining is localized in cell nuclei (n) as well as the basal cytoplasm (arrow). Magnification: 300×. (C) Detection of programmed cell death by the ISCDDK system. The red azo-dye staining is localized in many secretory cell nuclei (arrow). Magnification: $200 \times$. FB = fat body, $\mathrm{S}=$ secretion, lu = lumen.

product was observed throughout the cytoplasm (Fig. 2B), but the nuclei did not exhibit HSP90 activity as observed in the salivary glands of the untreated control larvae (Fig. 1C).

Forty-eight hours after the honeybee larvae were exposed to rotenone (Fig. 3), the nuclei of secretory cells showed intense positivereaction product, corresponding to HSP70 activity, and spots of reaction product were observed throughout the cytoplasm (Fig. 3A). The location of HSP90 immunoreactivity was similar to that in the untreated control larvae (Fig. 1C), but the level of activity in the nuclei appeared to be higher in the treated larvae (Fig. 3B).

Using the ISCDDK test kit, we could show that the application of rotenone to honeybee larvae did not change the level of cell death, as indicated by the red azo-dye reaction product in the nuclei of secretory cells (Figs. 2C, $3 \mathrm{C}$ ), in comparison with the salivary glands of the untreated control larvae (Fig. 1D). Furthermore, this treatment did not promote any observable morphological alteration of the secretory cells.

\subsection{Larvae treated with oxalic acid (OA)}

Six hours after the honeybee larvae were exposed to the OA solution, morphological alterations were observed in the secretory cells, such as cytoplasmic condensation and cell separation (Fig. 4). The level of positive-reaction product determining HSP70 activity was intense in the cytoplasm as well as in the nuclei of the secretory cells (Fig. 4A). HSP90 was detected throughout the cytoplasm (Fig. 4B).

Forty-eight hours after the honeybee larvae were exposed to OA (Fig. 5), the reaction product indicating HSP70 localization remained throughout the cytoplasm, but the intensity of the positive-reaction product in the nuclei decreased (Fig. 5A). The reaction product indicating HSP90 localization was observed throughout the cytoplasm in many secretory cells and in most of the nuclei (Fig. 5B). These secretory cells showed an apparently higher degree of cellular degeneration in comparison with the anterior treatment (Fig. 4).

Using the ISCDDK test kit we could show that the application of oxalic acid to honeybee larvae increased the level of cell death, as 

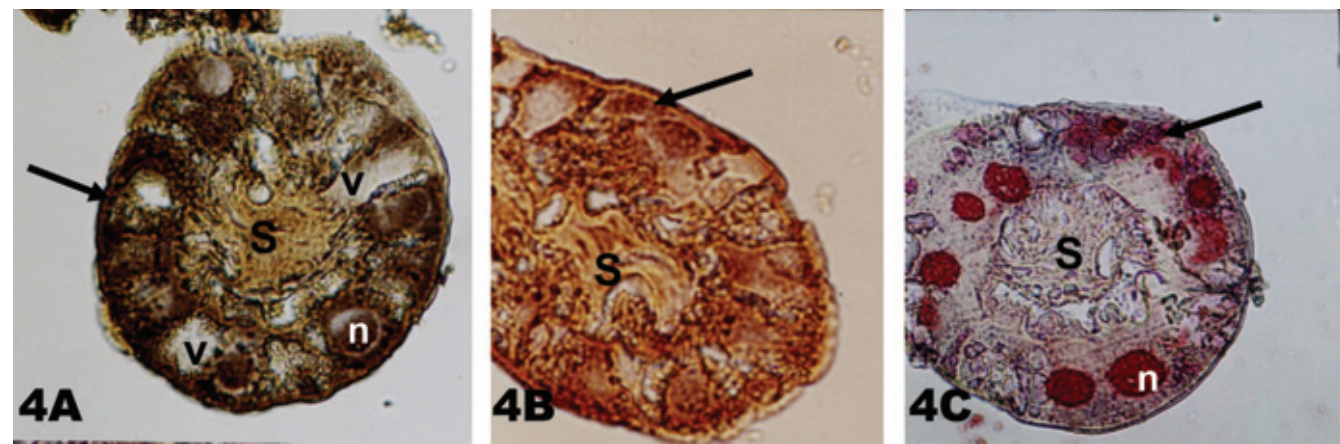

Figure 4. Secretory cells of formalin-fixed, paraffin-embedded salivary glands of larvae at the end of their 5th instar, collected 6 hours after the oxalic acid (AO) treatment. (A) Detection of HSP70 by a monoclonal antibody. Dense DAB-reaction product is localized in the nuclei (n) and throughout the cytoplasm (arrow). DAB-reaction product is absent from the vacuolated regions (v) of the cells. Magnification: $300 \times$. (B) Detection of HSP90 by a monoclonal antibody. Intensive DAB-reaction product (arrow) is localized throughout the cytoplasm of cells, which have also suffered morphological alterations. Magnification: $300 \times$. (C) Detection of programmed cell death by the ISCDDK system. Red azo-dye staining is intensively localized in all the secretory cell nuclei (n). Cytoplasmic red azo-dye staining can be observed in some regions of the cells (arrow). Magnification: $300 \times . \mathrm{S}=$ secretion.
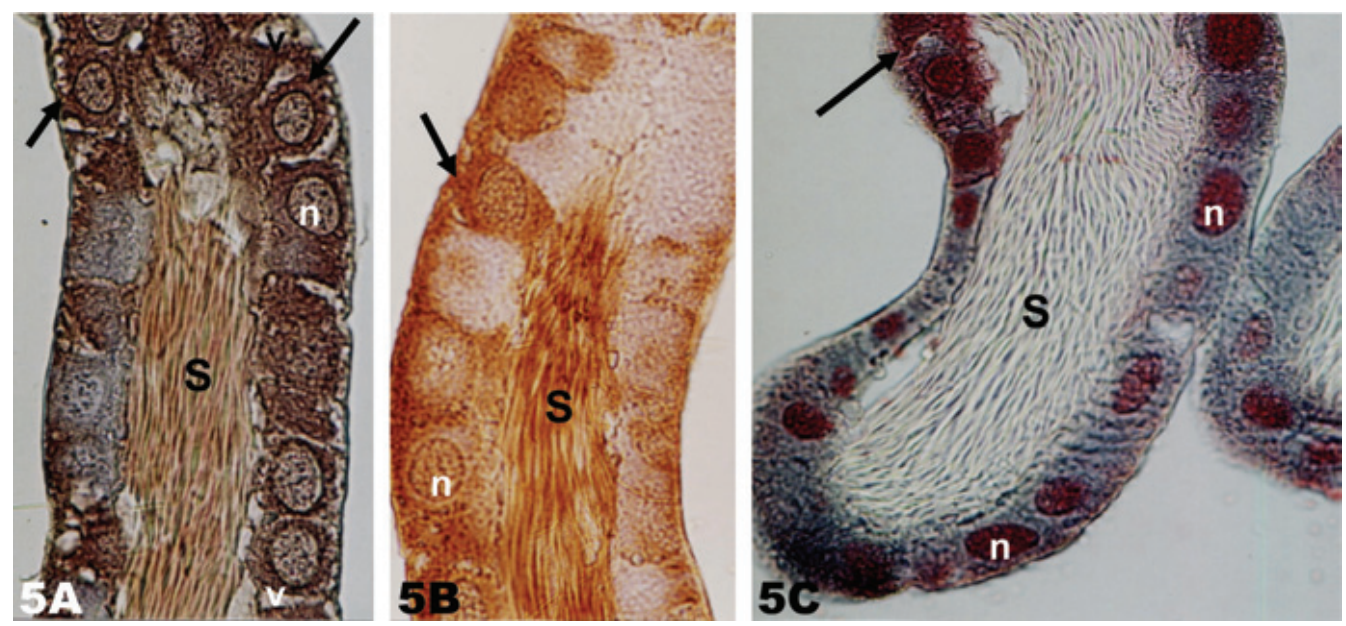

Figure 5. Secretory cells of formalin-fixed, paraffin-embedded salivary glands of larvae at the end of their 5th instar, collected 48 hours after the oxalic acid (AO) treatment. (A) Detection of HSP70 by a monoclonal antibody. DAB-reaction product is localized in the nuclei (n) and throughout the cytoplasm (arrow), except in the vacuolated areas (v). Magnification: $400 \times$. (B) Detection of HSP90 by a monoclonal antibody. Intensive DAB-reaction product is localized throughout the cytoplasm of cells (arrow) while the nuclei (n) display a weak positive colouring. Magnification: 400x. (C) Detection of programmed cell death by the ISCDDK system. Specific red azo-dye staining is localized in the secretory cell nuclei (n). Cytoplasmic red azo-dye staining can be observed in some regions of the cells (arrow). Magnification: $300 \times . \mathrm{S}=$ secretion. 
indicated by the intensified level of red azodye reaction product in the nuclei of secretory cells (Figs. 4C, 5C), in comparison with the salivary glands of the untreated control larvae (Fig. 1D).

\section{DISCUSSION}

The HSP70 and HSP90 families are present in a wide variety of unstressed cells (Pelham, 1986; Garrido et al., 2001), and in this study we detected HSPs in the cytoplasm and/or nuclei of salivary gland secretory cells, both under stress as well as in normal conditions. In the untreated control larvae, the immunohistochemical assays detected both HSC70 (heat shock "cognate" constitutively expressed in cells) and HSP70 (probably expressed at the end of the 5th instar when the glandular degeneration normally begins). In unstressed cells, members of the HSP70 family function as ATP-dependent molecular chaperones by assisting the folding of newly-synthesized polypeptides, the assembly of multi-protein complexes and the transport of proteins across cellular membranes (Beckmann et al., 1990; Shi and Thomas, 1992; Murakami et al., 1988). Members of the HSP70 family recognize nascent proteins and correct any aggregation that may occur during their folding and assembly into oligomeric structures (Pelham, 1986). Such a function would be consistent with the high concentration of members of the HSP70 family in the glands at the end of the 5th instar, when the cellular ultrastructural analysis of the cytoplasm reflects a high level of protein synthesis in the secretory cells, prior to the intensive degenerative process in the gland (Silva, 2002).

Under normal conditions, as observed in the untreated larvae of Apis mellifera, a large amount of HSP90 was observed in the cytoplasm of the secretory cells. It is known that HSP90 interacts with several protein-tyrosine kinases between the time of their synthesis and their ultimate association with the plasma membrane and with steroid receptors when they are not occupied by a hormone (Pelham, 1986). In untreated control larvae, HSP90 may also be associated with the conformational maturation of ecdysone-receptors, which are expressed at the end of the larval period to act in the programmed cell death of salivary glands (Kamimura et al., 1999).

The immunohistochemical data presented a highly-specific nuclear localization of HSP70 under conditions of stress in honeybee larvae treated with rotenone. Rotenone is a powerful inhibitor of mitochondrial electron transport and this oxidative stress induces HSP70 expression (Garrido et al., 2001). It is known that newly-synthesized HSP70 migrates to the nucleus and can concentrate in the nucleolus, where it apparently binds to partiallyassembled ribosomes in order to repair damaged pre-ribosomes (Pelham, 1986). In this way, protein synthesis in the cytoplasm is not affected and, accordingly, the programmed cell death in Apis salivary glands can occur normally at the end of the 5th instar.

An increased localization of HSP70 in the basal cytoplasm was observed within 6 hours after the application of rotenone. The cytoplasmic localization of stress-induced HSP70 coincides with the mitochondria-riche cellular region (Silva, 2002). Wong et al. (1998) suggested that HSP70 may protect cells from energy deprivation and/or ATP depletion associated with cell death. In rotenone-treated larvae we observed an intensive localization of HSP70 in the nuclei and basal cytoplasm of salivary gland cells, probably due to its suppressive effect of mitochondrial damage and nuclear fragmentation (Buzzard et al., 1998) and its maintenance of the features of secretory cells. This suggests HSP70 has an antiapoptotic effect. However, additional experiments must be performed to test this hypothesis.

The treatment of honeybee larvae with rotenone did not promote an increase in cell death large enough to be detected by the ISCDDK, nor did it provoke notable morphological changes in the secretory cells. It is probable that the synthesis of stress-induced HSP70 enhances the ability of stressed cells to cope with increased concentrations of unfolded or denaturated proteins (Nollen et al., 1999). In these honeybee larvae, HSP90 staining was highly intensive in the cytoplasm of salivary gland cells, in accordance with the idea that HSP90 may act as a chaperone, given the large 
quantity of unfolded or denaturated proteins likely to be present in these stressed cells.

Furthermore, coincident with the increase in stress-induced HSP70 in the nucleus and in the cytoplasm of cells of honeybee larvae 6 hours after OA application, the glands also showed both morphological cell alterations and an increase in cell death signs. Probably, the concentration of oxalic acid used in the experiment promoted a higher degree of stress than the cells could support. In this way, the overexpression of HSP70 and HSP90 could not have been sufficient to inhibit massive cell death.

In this experiment, it was evident that there was only a slight degree of morphological alteration in the gland cells 48 hours after OA application, even though a high degree of DNA strand breakage, which is indicative of cell death, was observed in the nuclei. It is probable that some larvae are either more sensitive to OA application than others, or that the quantity of OA consumed by the larvae varied during the longer exposure to OA present on the comb.

Some cytoplasmic staining (red azo-dye) observed in gland cells of honeybee larvae treated with OA seems to be indicative of DNA fragments released from altered cell nuclei. This has also been observed in the midgut cells of honeybee larvae infected by Paenibacillus (Gregorc and Bowen, 2000). OA application to honeybee larvae also affected the columnar cells of their midgut (Gregorc et al., 2004). Furthermore, Gregorc and Bowen (2000) reported that ISCDDK testing of honeybee larvae treated with acaricides revealed both programmed cell death and stress-induced cell death, indicating that these different types of cell death were occurring simultaneously (Matylevitch et al., 1998).

Our results showed that in biological and toxicological studies of honeybees, the in situ labelling of DNA strand breaks using ISCDDK and the determination of HSP localization can be useful immunohistochemical methods for demonstrating and better understanding any possible adverse (sublethal) effects. Such a combination of the immunohistochemical assays may help to detect the cellular responses of larval tissue suffering from different chemical stressors from within their environment. These methods are, thus, potentially powerful tools for diagnosis in biological models and can be explored in future research to evaluate the threshold effects of substances used in bee colonies.

\section{ACKNOWLEDGEMENTS}

The authors would like to thank Jasna Sporar for her technical help. The support given by FAPESP (Fundação de Amparo à Pesquisa do Estado de São Paulo - Brazil), the Slovenian Ministry of Science and Technology and the Ministry of Agriculture, Forestry and Food (Research programme P4-0072 and project No. V4-0759-0406-02) is also gratefully acknowledged.

Résumé - Localisation in situ des protéines de choc thermique et marquage de la mort cellulaire dans la glande salivaire d'abeilles traitées à l'acaricide. Les acaricides sont les sources chimiques de stress que les larves d'abeilles domestiques (Apis mellifera L.) rencontrent le plus communément sur le terrain. Le but de cette étude était de déterminer si traiter des larves d'abeilles avec un produit «alternatif » contre Varroa destructor, comme l'acide oxalique (AO), ou avec un insecticide tel que la roténone pouvait induire une surexpression des protéines de choc thermique (HSP) et/ou la mort cellulaire dans les glandes salivaires d'A. mellifera.

Des larves d'abeilles ont été traitées dans le rayon avec une solution d'acide oxalique $(\mathrm{AO} /$ saccharose $=2,97 \% / 31,95 \%$ poids $/$ poids $)$, vaporisée sur le rayon de sorte que chaque larve reçoive $0,121 \mathrm{mg}$ de la solution. La roténone a été tamisée sur les rayons de façon à répartir la substance uniformément dans les cellules de couvain. Les larves ont été traitées avec $0,5 \mathrm{~g}$ de roténone à $1 \%$, si bien que chaque larve en a reçu une dose de $0,29 \mathrm{~g}$. Les rayons, qui contenaient soit des larves traitées à l'AO, soit des larves traitées à la roténone, ont été replacés dans leur colonie d'origine. Deux lots d'échantillons (larves au $5^{\mathrm{e}}$ stade) ont été prélevés l'un $6 \mathrm{~h}$, l'autre $48 \mathrm{~h}$ après le traitement. Des échantillons de larves non traitées «témoins » ont été prélevés à la fin du $5^{\mathrm{e}}$ stade. Les larves de chaque groupe ont été disséquées, leurs glandes salivaires isolées, fixées dans une solution saline de formol à $10 \%$ et montées dans la paraffine. Des tests d'immunohistochimie ont été appliqués aux coupes histologiques afin de détecter la mort cellulaire (kit de détection in situ ISCDDK) et de localiser les protéines de choc thermique (HSP). On a détecté les HSP70 et HSP90 dans le cytoplasme et/ou dans les noyaux des cellules 
sécrétrices, à la fois dans les conditions normales et dans les conditions de stress. Les larves traitées à la roténone ont présenté une coloration intense de HSP70 dans les noyaux et le cytoplasme basal des cellules des glandes salivaires, probablement en raison de la fonction de protection de cette protéine contre les dommages aux mitochondries et contre la fragmentation nucléaire. Cela suggère que la HSP70 peut avoir un effet antiapoptotique (contre la mort cellulaire programmée). Le traitement à la roténone n'a pas modifié le niveau de mort cellulaire dans les cellules sécrétrices des glandes salivaires, ni provoqué de modifications physiologiques. Chez les larves traitées à l'AO, on a observé une augmentation du marquage de HSP70 induites par le stress dans le noyau et le cytoplasme, ainsi qu'une coloration très intense pour HSP90, principalement dans le cytoplasme des cellules stressées. HSP90 pourrait servir de chaperon étant donné la grande quantité de protéines dépliées ou dénaturées présentes dans les cellules stressées. Les glandes montrent également des degrés variables d'altération morphologique de la cellule et une augmentation du niveau de mort cellulaire.

Apis mellifera / glande salivaire / stress cellulaire / immunohistochimie / roténone / acide oxalique

Zusammenfassung - In situ-Lokalisierung von Hitzschockproteinen und Zelltodmarkern in Speicheldrüsen von Akarizid-behandelten Honigbienenlarven. Akarizide sind die häufigsten chemischen Stressfaktoren für Bienenlarven. In dieser Studie untersuchten wir, ob die Behandlung von Honigbienenlarven mit ,,alternativen“"VarroaKontrollsubstanzen, wie z.B. Oxalsäure (OA), oder mit einem Akarizid wie Rotenon zur Überexpression von Hitzeschockproteinen und/oder Zelltod in den Speicheldrüsen führen kann. Apis mellifera Larven wurden in den Waben mit Oxalsäurelösung (OA/Saccharose im Verhältnis 2,97 \%/31,95\% (w/w)) besprüht, so dass jede Larve mit 0,121 mg OA-Lösung behandelt wurde. Rotenon wurde über die Waben gesiebt, um diese Substanz gleichmässing über die Brutzellen zu verteilen. Die Larven wurden mit $0,5 \mathrm{~g}$ eines $1 \%$ Rotenonpräparats behandelt, so dass die Dosis pro Larve 0,29 mg des Produkts entsprach. Die mit Oxalsäure oder Rotenon behandelten Waben wurden in die Völker zurückgegeben, aus denen sie entnommen worden waren. Als Proben wurden Larven im 5. Stadium 6 Stunden, bzw. 48 Stunden nach der Behandlung entnommen. Als Kontrollen wurden unbehandelte Larven im 5. Stadium entnommen. Die Larven wurden präpariert und die Speicheldrüsen entnommen. Nach der Fixierung in $10 \%$ Formol (in Saline) wurden diese in Paraffin eingebettet. Die Immunhistologie für Zelltodmarker (in situ cell death detection kit, ISDDK) und Hitzeschockproteinen (HSP) wur- de an histologischen Schnitten durchgeführt. Hitzeschockproteine (HSP70 und 90) konnten im Cytoplasma und/oder den Kernen der Speicheldrüsen nachgewiesen werden, sowohl bei behandelten als auch bei Kontrollarven. Rotenon-behandelte Larven wiesen eine starke Färbung für HSP70 in den Kernen und im basalen Cytoplasma auf, vermutlich aufgrund der Schutzfunktion von HSP70 gegen mitochondriale Schädigung und Kernfragmentierung. Dieser Befund weist auf einen antiapoptotischen Effekt für HSP70 hin. Die Rotenon-Behandlung bewirkte keine Veränderung in der Zelltodrate und hatte auch keine morphologischen Veränderungen in den sekretorischen Zellen der Speicheldrüsen zur Folge. In den mit Oxalsäure behandelten Larven beobachteten wir einen Anstieg in der stressinduzierten HSP70-Markierung in den Kernen und im Cytoplasma, sowie eine sehr starke HSP90-Markierung im Cytoplasma. HSP90 könnte hier eine Rolle als Chaperon spielen, als Folge der grossen Menge an entfalteten und denaturierten Proteinen in den gestressten Zellen. Die Drüsen zeigten ausserdem variierende morphologische Veränderungen und eine erhöhte Zelltodrate.

Apis mellifera / Speicheldrüse / zellulärer Stress / Immunhistochemie / Rotenon / Oxalsäure

\section{REFERENCES}

Armbruster L., Levy M., Mathieu M.N., Bautz A.M. (1986) Acid phosphatase activity in the hemolymph, hemocytes, fat body and salivary glands during larval and prepupal development in Calliphora erythrocephala (Diptera: Calliphoridae), J. Biochem. Physiol. B 84, 349354.

Beckmann R.P., Mizzen L.A., Welch W.J. (1990) Interaction of Hsp70 with newly synthesized proteins: implications for protein folding and assembly, Science 248, 850-854.

Bowen I.D., Lockshin R.A. (1981) Cell Death in Biology and Pathology, Chapman and Hall, London, New York.

Buzzard K.A., Giaccia A.J., Killender M., Anderson R.L. (1998) Heat shock protein 72 modulates pathways of stress-induced apoptosis, J. Biol. Chem. 273, 17147-17153.

Chiang H., Terlecky S.R., Plant C.P., Dice J.F. (1989) A role for a 70-kilodalton heat shock protein in lysosomal degradation of intracellular proteins, Science 246, 382-385.

Garrido C., Gurbuxani S., Ravagnan L., Kroemer G. (2001) Heat shock proteins: endogenous modulators of apoptotic cell death, Biochem. Biophys. Res. Comm. 286, 433-442.

Gregorc A., Bowen I.D. (1998) Histopathological and histochemical changes in honeybee larvae (Apis 
mellifera L.) after infection with Bacillus larvae, the causative agent of American foulbrood disease, Cell Biol. Int. 22, 137-144.

Gregorc A., Bowen I.D. (1999) In situ localization of heat-shock and histone proteins in honeybee (Apis mellifera L.) larvae infected with Paenibacillus larvae, Cell Biol. Int. 23, 211-218.

Gregorc A., Bowen I.D. (2000) Histochemical characterization of cell death in honeybee larvae midgut after treatment with Paenibacillus larvae, Amitraz and Oxytetracycline, Cell Biol. Int. 24, 319-324.

Gregorc A., Pogacnik A., Bowen I.D. (2004) Cell death in honeybee (Apis mellifera) larvae treated with oxalic or formic acid, Apidologie 35, 453460.

Kamimura M., Takahashi M., Tomita S., Fujiwara H., Kiuchi M. (1999) Expression of ecdysone receptor isoforms and trehalase in the anterior silk gland of Bombyx mori during an extra larval molt and precocious pupation induced by 20 -hydroxyecdysone administration, Arch. Insect Biochem. Physiol. 41, 79-88.

Kohler H.R., Triebskorn R., Stocker W., Kloetzel P.M., Alberti G. (1992) The $70 \mathrm{kD}$ heat shock protein (HSP 70) in soil invertebrates: a possible tool for monitoring environmental toxicants, Arch. Environ. Contam. Toxicol. 22, 334-338.

Levy M., Bautz A.M. (1985) Degeneration of larval salivary glands during metamorphosis of the blowfly Calliphora erythrocephala Meigen (Diptera: Calliphoridae), Int. J. Insect Morphol. Embryol. 14, 281-290.

Lindquist S., Craig E.A. (1988) The heat-shock proteins, Annu. Rev. Genet. 22, 631-677.

Matylevitch N.P., Schuschereba S.T., Mata J.R., Gilligan G.R., Lawlor D.F., Goodwin C.W., Bowman P.D. (1998) Apoptosis and accidental cell death in cultured human keratinocytes after thermal injury, Am. J. Pathol. 153, 567-577.

Meirelles R.M.S., Silva E.C.M., Silva de Moraes R.L.M. (2001) Lipid distribution in salivary glands of larvae and adult bees (Hymenoptera: Apidae), Cytobios 106, 57-66.
Mosser D.D., Caron A.W., Bourget L., Denis-Larose C., Massie B. (1997) Role of human heat shock protein hsp70 in protection against stress-induced apoptosis, Mol. Cell Biol. 17, 5317-5327.

Murakami H., Pain D., Blobel G. (1988) 70-kD heat shock-related protein is one of at least two distinct cytosolic factors stimulating protein import into mitochondria, J. Cell Biol. 107, 2051-2057.

Nollen E.A., Brusting J.F., Roelofsen H., Weber L.A., Kampinga H.H. (1999) In vivo chaperone activity of heat shock protein 70 and thermotolerance, Mol. Cell Biol. 11, 2069-2079.

Papaefthimiou C., Pavlidou V., Gregorc A., Theophilidis G. (2002) The action of 2,4dichlorophenoxyacetic acid on the isolated heart of insect and amphibia, Environ. Toxicol. Pharmacol. 11, 127-140.

Pelham H.R.B. (1986) Speculations on the functions of the major heat shock and glucose-regulated proteins, Cell 46, 959-961.

de Pomerai D.I. (1996) Heat-shock proteins as biomarkers of pollution, Hum. Exp. Toxicol. 15, 279-285.

Rassow J., Voos W., Pfanner N. (1995) Partner proteins determine multiple functions of Hsp70, T. Cell Biol. 5, 207-212.

Shi Y., Thomas J.O. (1992) The transport of proteins into the nucleus requires the 70-kilodalton heat shock protein or its cytosolic cognate, Mol. Cell Biol. 12, 2186-2192.

Silva E.C.M. (2002) Glândulas salivares larvais das abelhas, in: Cruz-Landim C., Abdalla F.C. (Eds.), Glândulas exócrinas das abelhas, Funpec, Ribeirão Preto/Brasil, pp. 21-49.

Silva-Zacarin E.C.M., Silva de Moraes R.L.M., Taboga S.R. (2003) Silk formation mechanisms in the larval salivary glands of Apis mellifera (Hymenoptera: Apidae), J. Biosci. 28, 753-764.

Wong H.R., Menendez I.Y., Ryan M.A., Denenberg A.G., Wispe J.R. (1998) Increased expression of heat shock protein-70 protects A549 cells against hyperoxia, Am. J. Physiol. 275, 836-841. 